\title{
An Examination of Causes of Accidents and Hazards in the Ghanaian Construction Industry
}

\author{
Dickson Osei-Asibey*, Joshua Ayarkwa, Alex Acheampong, Emmanuel Adinyira, Peter Amoah \\ Department of Construction Technology and Management, Kwame Nkrumah University of Science and Technology (KNUST), \\ Kumasi, Ghana \\ Email: *dosei-asibey@knust.edu.gh
}

How to cite this paper: Osei-Asibey, D. Ayarkwa, J., Acheampong, A., Adinyira, E. and Amoah, P. (2021) An Examination of Causes of Accidents and Hazards in the Ghanaian Construction Industry. Open Journal of Safety Science and Technology, 11, 66-88.

https://doi.org/10.4236/ojsst.2021.112006

Received: April 23, 2021

Accepted: June 20, 2021

Published: June 23, 2021

Copyright (c) 2021 by author(s) and Scientific Research Publishing Inc. This work is licensed under the Creative Commons Attribution International License (CC BY 4.0).

http://creativecommons.org/licenses/by/4.0/

\begin{abstract}
This study aims to examine the causes of accidents and hazards in the Ghanaian construction industry (GCI) from the perspectives of key stakeholders, and also the available legal regulations and provisions regarding remedies for redress in case of accidents. A qualitative research strategy with in-depth face-to-face interviews was adopted. Participants for the interview were seven of which are Contractors, Consultants, Construction Workers, and Suppliers/ Manufacturers using data saturation principle. The selection of interview participants was based on purposive sampling, while data was analyzed using the content analysis technique. Five major causes of accidents and hazards that are critical for remedying were identified, including common law liabilities of the Employer who is the Contractor, with a duty to ensure that adequate provisions are made for the works to be carried out safely. The findings of the study provide adequate knowledge to the contractor and other stakeholders of the roles, duties, and responsibilities to ensure improved implementation of CHS practices. The study examined the legal basis and consequences for causes of accidents and hazards in the Construction Industry. Since large construction firms were considered in the current study, it is recommended that similar studies be conducted involving small and medium enterprises.
\end{abstract}

\section{Keywords}

Causes, Accidents, Hazards, Construction Industry, Legal Consequence

\section{Introduction}

The construction industry plays a significant role in the development of countries, with 350 million people around the world directly involved in this sector, and the number keeps growing rapidly in cities [1]. The construction industry 
should not only be commended for providing infrastructure to a nation but also for contributing greatly to the economy of every nation. The industry serves as a great source of employment and also sustains the economy of the country.

However, due to several occupational health risks, this sector is placed top of the list in terms of workplace accidents and injuries. Workers in this sector are daily exposed to several types of fatal occupational health hazards [2]. The construction industry of every country is responsible for procuring its infrastructure, and combining available resources to produce long term, unique and complex buildings, dam, roads, bridges, and other infrastructure [3]. The construction industry stands out among other industries due to its unique processes and activities. These include working in confined spaces, working at heights, manual handling, lifting operations, demolition works, and ground works. All these activities involve risks and are very hazardous in nature [4]. Accidents occur every day and, one way or another, will impact virtually everyone [5]. According to Biswas et al. [6], construction projects generally involve activities that are high in risks, uncertainties, and complexities. The construction industry of most developing countries, often fall victim to construction accidents and hazards due to non-existing or unenforceable regulations [7]. During the year 2012, there were more than 2.8 million on-the-job non-fatal injuries in the United States [8]. DeCamp \& Herskovitz [4] reported that in Malaysia, out of the total number of 112 reported fatal injuries in September 2015, 42 deaths were recorded from the construction industry. This statistic indicates that the construction industry is among the most hazardous in Malaysia. Ghana's construction industry records the highest number of occupational hazards and accidents compared to other industries in the country. Fifty-six percent (56\%) of 902 occupational injuries and accidents recorded in the year 2000 resulted in death. These statistics show that attention ought to be given to occupational health and safety in the construction industry of every economy.

The National Safety Council is reported to define an accident as an undesired event that results in personal injury or property damage [9]. This definition in the opinion of [9] implies two important points. First, accidents are unavoidable; the chance of one occurring will virtually always be present. Second, the chance of an accident occurring is a variable that can be changed. While it is impossible to prevent all accidents, it is possible to decrease their rate of occurrence. Understanding the cause of such a phenomenon is key to decreasing the rate at which accidents occur. Determining the true root cause of each accident is the only way to formulate effective prevention strategies [9].

While the myriad of causes has been identified in existing literature, this paper seeks to examine the causes of accidents and hazards in the GCI from the perspectives of key stakeholders, and also the available legal regulations and provisions regarding remedies for redress in case of accidents.

\subsection{Ghanaian Construction Industry}

The construction industry in Ghana, just as in other countries, is a major con- 
tributor to economic development. Being among the top drivers of the Ghanaian economy [10], its importance cannot be over emphasized, especially as the country is one of the most economically vibrant in West Africa. The construction industry largely depends on human resources (labour force). The labourintensive approach however is preferred by contractors since it is readily available at a cheaper cost [10]. The stakeholders in the construction industry in Ghana include clients, professional consultants, contractors, suppliers, statutory authorities, and the community or traditional authorities (Figure 1).

Construction work is carried out in constantly changing working environments, and this poses significant health and safety risks such as injuries, accidents, and loss of skilled workers [11]. The accidents and hazards that occur are very costly to the industry and all its stakeholders.

\subsection{Accidents and Hazards}

Accidents are unplanned or unforeseen occurrences that result in injuries, and cause unexpected damages. These accidents are, however, unavoidable in the industry and remain the main disadvantage in the construction industry [12]. According to Chong \& Low [13], the inherent hazards and the nature of the

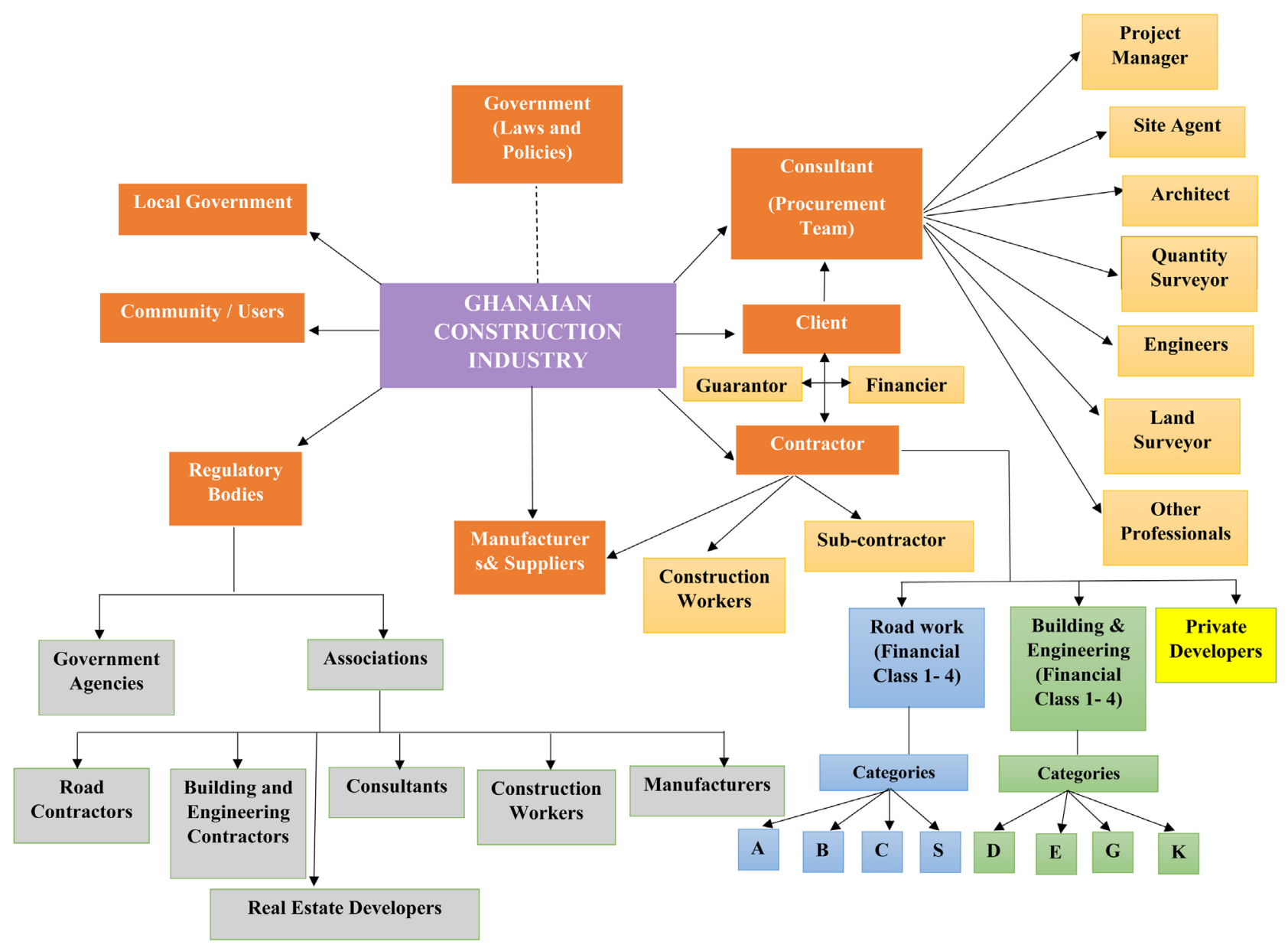

Figure 1. Stakeholders of Ghanaian construction industry. Source: [15]. 
activities of the construction industry contribute to occupational injuries. Furthermore, Chong \& Low [13] also emphasized that there are three types of hazards which need to be recognized and controlled in all industries, especially in the construction industry: chemical, physical and biological. Physical hazards may result in direct injury or internal bleeding to a worker on a site. Secondly, poor communication and co-ordination between management and employees are causes of accidents, as some workers come from various countries and some do not speak or understand the local language. Accidents and hazards in the construction industry have been classified in various forms [14].

For instance, Ramachandran [16] grouped construction accidents and hazards into three main classifications viz: 1) According to the severity of the injury; 2) According to the nature of injury; 3 ) According to the cause of accident or hazard.

Ramachandran [16] stated that accidents and hazards that are grouped according to the severity of injury are further grouped into major accidents and hazards, minor accidents and hazards, and accidents and hazards. Moreover, accidents and hazards grouped according to the nature of injury, are further grouped into death, temporary disablement, permanent disablement, and partial disablement [16]. According to Ramachandran [16], the third category of accidents and hazards relates to the construction activities that lead to the cause of accidents and hazards. Accidents and hazards belonging to the originality influences are regarded as the root causes of accidents and hazards [17]. These causal factors directly relate to the works design and project management techniques. In fact, inaccurate designs and poor construction supervision may cause a newly constructed structure to fail and collapse, causing accidents and hazards. In such instances, heavy duty vehicles could knock workers down; also, there is the possibility of double handling of materials which could result in accidents and hazards [18].

Causes of accidents and hazards relating to materials and equipment include, the variability in the quality of construction materials, lack of information regarding the usage of materials and equipment, and the use of contaminated materials. The quality of construction materials and equipment, lack of information on how equipment and materials are to be used, often expose construction operatives to accidents and hazards. It is therefore important for manufacturers and suppliers to provide adequate information on the usage of materials and equipment on site. Moreover, suppliers must avoid distributing faulty and expired equipment and materials for construction works [19].

Wong et al. [20] also identified improper equipment and working platform, wrong safety attitude and inadequate housekeeping as the underlining causes of construction accidents and hazards. It is obvious that the poor usage of equipment and bad safety attitude towards safety exposes the workers and even pedestrians to accidents, hazards and injuries. Moreover, poor supervision and monitoring, and improper procedures and safety guidelines could also contribute to 
accidents and hazards on site [20].

Jafar et al. [1] developed a framework for causes of occupational accidents and illnesses in the construction industry. This framework consists of four main elements: human, worksite, management, and external elements. In this framework, human and worksite elements have been further identified as the immediate causes while management and external elements are classified as the originating influences/underlying causes. Human and worksite elements are considered the most immediate causes of occupational accidents and hazards. Therefore, all of the items included in these elements are considered to have the characteristics of immediate causes, which are easier to identify during investigation, compared with the underlying causes [21].

In the Ghanaian construction industry, Laryea [22] identified that lack of strong institutional framework governing construction activities, poor enforcement of health and safety policies and procedures, and the fact that the Ghanaian society does not place a high premium on the health and safety of construction workers on site, are the primary reasons for the poor state of health and safety on the Ghanaian construction sites. Eyiah et al. [23] also suggested that legal and regulatory challenges, among other factors, contribute to low occupational health and safety (OHS) performance in Ghana. Due to the costly nature of accidents and hazards in the construction industry, all stakeholders or parties to a contract must be committed to addressing the causes of accidents and hazards on the construction site.

Proper accident investigation ought to be employed in order to curb the repetition of the same accident on site. Moreover, the management team concerned with where the accidents occurred should take part in the accident investigation [24]. It is also needful for the worker's representative and safety officer to be part of the investigation team [25]. The outcome of these investigations should be made available to all stakeholders of the contract so as to help prevent future occurrences of the accident or hazard.

\section{Research Methodology}

In examining the causes of accidents and hazards on a construction site, the qualitative research strategy was adopted, and the research instrument used was indepth face-to-face interviews. A qualitative approach was chosen because it reveals existing knowledge in the form of questions and answers and its' results are easily accessible to interpret [26]. Gay et al. [27] also emphasized that qualitative approach gives a large quantity of in-depth information. This allows the researcher to gather more information by acting as an interviewer who forms part of the data collection process. The interview guide was structured into two sections. The first section gathered some background information of the respondents while the second section sought the views of the respondents on the causes of accidents and hazards in the GCI.

Participants for the interview were seven of which are Contractors, Consul- 
tants, Construction Workers and Suppliers/Manufacturers. Data Saturation principle was used in limiting the number of each stakeholder group to 7. Data saturation used in this sense refers to a point at which new or additional yielded by the interviews provided no insights regarding the research questions posed [28] [29] [23]. This means that the number of interviews progressed up to a point where no additional/new insights on the research objectives were obtained from the study participants [23]. Further, Eyiah et al. [23] argued that interviews were therefore unnecessary as they were thought by the researchers to yield no additional insights to enable the research objectives to be achieved. In this study, the Contractor group has been considered as the fulcrum around which all the stakeholders revolved. The seven contractor interviewees provided saturated data, and to have common number for all the stakeholders, seven interviewees of each of the other stakeholder groups were selected.

The professionals working with Contractors in the class and categories D1K1 and $\mathrm{A} 1 \mathrm{~B} 1$ with at least 5 years' working experience were selected due to the fact that these are the large and experienced construction firms that are likely to make the effort to comply with the health and safety requirements. Similarly, the professionals working with the Consulting firms belonging to professional bodies such as Ghana Institute of Architects (GIA), Ghana Institution of Engineering (GhIE), and Ghana Institution of Surveyors (GhIS), with at least 10 years' working experience were selected. The Construction Workers with not less than 10 years' working experience working with Construction firms of D1K1 and A1B1 were selected. The Supplier/Manufacturer with at least 5 years' experience in the business having at least two depots of construction material and or equipment were also selected. In purposively selecting participants, the criteria for the various research participants are outlined in Table 1 . The selected interviewees were therefore experienced in the GCI and their views were considered reliable and credible.

The selection of interview participants was based on a purposive sampling technique for all categories of participants. This sampling approach was adopted in order to have in-depth information on the phenomenon under study. Purposive sampling was adopted also to ensure that persons familiar with the principles and management of construction health and safety were interviewed. In all, twenty-eight (28) participants were involved in the interview. The interviewees responded on the questions in relation to causes of accidents and hazards in the GCI. The participants were taken through a well-focused interview using semi-structured open-ended questions. This provided participants the opportunity to elaborate more on the subject matter being discussed. Prior to the fixing of interview date, the open-ended questions were sent to all interviewees. To allow for convenience of the interviewees, the interview session took place in the offices of the interviewees, except for certain interviewees without offices where the interviews took place in the comfort of their residence or other convenient places. 
Table 1. Criteria for group participants in interview.

\begin{tabular}{|c|c|c|}
\hline $\begin{array}{c}\text { Group } \\
\text { Participants }\end{array}$ & Number & Criteria \\
\hline $\begin{array}{l}\text { Contractors } \\
\text { (D1K1; A1B1) }\end{array}$ & 7 & $\begin{array}{l}\text { The professionals working with the D1K1 (General Building and } \\
\text { Civil Engineering category in Financial Class 1) or A1B1 (Road } \\
\text { and Concrete Structures Construction category in Financial } \\
\text { Class 1) class of contractors in Ghana. The interviewees belong } \\
\text { to the professional bodies and construction associations of their } \\
\text { status. They have experience between } 12 \text { and } 22 \text { years in the } \\
\text { construction industry. } \\
\text { The contractor must have a well-established health and safety } \\
\text { management system where there are good accidents and } \\
\text { hazards records procedures, safety kits, health and safety } \\
\text { policy and plan for projects. } \\
\text { The contractor must have engaged in construction projects in } \\
\text { two or more regions in Ghana. }\end{array}$ \\
\hline \multirow[t]{2}{*}{ Consultants } & \multirow[t]{2}{*}{7} & $\begin{array}{l}\text { The consultants must have had adequate knowledge and been } \\
\text { trained in the area of health and safety management. The } \\
\text { Consultants belong to the various professional bodies which are } \\
\text { well recognized in the GCI. The interviewees were personnel of } \\
\text { senior level and authority in their various Consulting firms. The } \\
\text { interviewees have experience of } 10 \text { to } 22 \text { years in their various } \\
\text { field of expertise. }\end{array}$ \\
\hline & & $\begin{array}{l}\text { The supplier/manufacturer must be a dealer of the major } \\
\text { construction materials such as cement, reinforcement } \\
\text { rods, roofing sheet and tiles. }\end{array}$ \\
\hline $\begin{array}{c}\text { Suppliers/ } \\
\text { Manufacturers }\end{array}$ & 7 & $\begin{array}{l}\text { The supplier/manufacturer must have depots across the major } \\
\text { cities in the country. All the supplier/manufacturer interviewees } \\
\text { must have more than two depots across the country. This } \\
\text { indicates that the respondents have enough experience in the } \\
\text { manufacturing and supply of construction materials in Ghana. }\end{array}$ \\
\hline $\begin{array}{l}\text { Construction } \\
\text { Workers }\end{array}$ & 7 & $\begin{array}{l}\text { The worker must have worked with a D1K1 or A1B1 classes of } \\
\text { contractors in Ghana for a minimum of five (5) years. The } \\
\text { selected construction workers must representatives of the } \\
\text { most active trades within the GCI. The years of experience } \\
\text { must range between } 11 \text { and } 20 \text { years in the GCI. }\end{array}$ \\
\hline Total & 28 & \\
\hline
\end{tabular}

Source: Authors.

On average, the interview section took between 45 and 60 minutes per participant. All but five interviewees were recorded by means of an audio recorder. The five interviewees indicated they would not be allowed to be recorded by means of an audio recorder. Their responses were then directly hand-written and later confirmed by them. The audio recordings of majority of the interviews were done to ensure the accuracy of notes taken from the field and more also to provide more rendition of an interview. The audio recordings were then transcribed by creating a verbatim text of each interview. The qualitative data (faceto-face interviews) were analyzed by means of the content analysis technique. Content analysis seeks to identify the main facets of a set of data by counting the 
number of times an activity or theme occurs [30]. The first step in content anal$y$ sis is the identification of the data or material to be analyzed. The second step is to identify the content technique to employ. The interview transcripts were analyzed by rereading the transcripts to identify the themes that emerged from the interview participants' answers. The themes were summarized in tables and the number of times it was mentioned by participants was tallied. There was regrouping on similar and closed responses. Each of the seven respondents in each of the identified organizations was given an identification code: an alphabet for the organization and a number from one to seven for the respondent. The first respondent of the Contractors, for example, was identified as CA1, the second respondent as CA2 and so on. The Pareto Chart was used to identify the most critical of the causes of accidents and hazards for redress.

\section{Results and Discussion}

The interviewees responded to questions in relation to causes of accidents and hazards in the GCI. From the content analysis, eight responses from all the interviewees as shown in Table 2 were identified as: (F1) Low level of education; (F2) Bad attitude towards work safety; (F3) Lack of appropriate skills; (F4) Lack of communication among stakeholders; (F5) Poor working conditions and environment; (F6) Inadequate equipment and tools; (F7) Lack of health and safety training among stakeholders; and (F8) Tiredness of workers.

Table 2. Causes of construction accidents and hazards.

\begin{tabular}{|c|c|c|c|c|c|c|}
\hline Code & Factors & $\begin{array}{l}\text { Contractors } \\
\text { (CR1-CR7) }\end{array}$ & $\begin{array}{l}\text { Consultant } \\
\text { (CT1-CT7) }\end{array}$ & $\begin{array}{c}\text { Workers } \\
\text { (CW1-CW7) }\end{array}$ & $\begin{array}{l}\text { Suppliers } \\
\text { (MS1-MS7) }\end{array}$ & $\begin{array}{c}\text { Total } \\
\text { Responses }\end{array}$ \\
\hline $\mathrm{F} 1$ & $\begin{array}{l}\text { Low level of } \\
\text { Education }\end{array}$ & 6 & - & - & 3 & 9 \\
\hline F2 & $\begin{array}{l}\text { Bad attitude to } \\
\text { work Safety }\end{array}$ & 5 & - & 2 & 3 & 10 \\
\hline F3 & $\begin{array}{l}\text { Lack of } \\
\text { Appropriate Skills }\end{array}$ & 4 & 4 & 5 & - & 13 \\
\hline $\mathrm{F} 4$ & $\begin{array}{l}\text { Lack of } \\
\text { Communication }\end{array}$ & 3 & - & - & 1 & 4 \\
\hline F5 & $\begin{array}{l}\text { Poor Working } \\
\text { conditions and } \\
\text { environment }\end{array}$ & 2 & - & 4 & - & 6 \\
\hline F6 & $\begin{array}{l}\text { Inadequate } \\
\text { Equipment \& Tools }\end{array}$ & 2 & 5 & 6 & 3 & 16 \\
\hline F7 & $\begin{array}{l}\text { Lack of Health \& } \\
\text { safety training of } \\
\text { workers }\end{array}$ & - & 6 & 2 & 7 & 15 \\
\hline \multirow[t]{2}{*}{ F8 } & $\begin{array}{l}\text { Tiredness of } \\
\text { Workers }\end{array}$ & - & - & 7 & - & 7 \\
\hline & Total & & & & & 80 \\
\hline
\end{tabular}

Source: Author's construct. 


\subsection{Contractors' Perspective on Causes of Construction Accidents and Hazards}

From the perspective of the contractors six responses from the seven interviewees were revealed. The interviewees revealed that the low level of education by workers is the major cause of accidents on construction sites. For example, CR1 noted that:

"Some of the construction workers cannot even read or write hence any safety signs and symbols posted for caution is not followed."

In ensuring health and safety, the level of education is very important. If one's educational background is high, it enables the person to read and understand the safety signs and symbols posted on site and this helps to avoid accidents as noted by CR6 and corroborated by CR4:

"Because of the low educational level of most construction workers, conducting health and safety training continuously is very important to increase the workers knowledge on how to read simple signs and symbols on construction site."

The bad attitude towards work safety was mentioned by five interviewees as another major cause of construction accidents. For example, CR3 indicated that:

"The bad attitude towards safety by workers exposes not only themselves but other pedestrians and the general public."

CR7 emphasized that:

"If workers would ensure a positive attitude towards safety, it will have a good effect on the reduction of construction accidents."

Bad attitude leads to carelessness and improper use of health and safety facilities that have been provided. Bad attitude towards safety was also identified by Wong et al. [20] as one of the major causes of construction accidents.

The lack of appropriate skills was also mentioned by four interviewees. Appropriate skills include possessing the required technical knowledge on the particular work being done. This was stated clearly by CR1 that:

"Most construction workers lack experience and technical skills on the work they do, which causes lots of errors and accidents. When workers have little knowledge on the work activity they do, the mistakes they make, at times causes injury to themselves and other workers."

CR6, corroborated by lamenting that:

"Contractors must engage workers with enough experience and technical skills for certain works especially works which are quite hazardous."

It may be deduced that Contractors are required to equally spend time and other resources to train those engaged on the various works in appropriate skills as they do for materials for the works. High cost equipment was also revealed to cause accidents as contractors are forced to use inappropriate or faulty equipment for the works. For example, CR5 revealed that:

"High cost of equipment makes it impossible for the contractors to own or even hire appropriate equipment for the specific works." 
CR7 was also of the opinion that:

"Even if you borrow to purchase the equipment, you cannot pay back the investment due to lack of continuous work for same equipment to sustain any payment plan."

Contractors therefore need many construction contracts to sustain the repayment of funds invested in construction equipment including the cost of borrowing.

\subsection{Consultants' Perspective}

From Table 2, three different responses were given by the Consultant interviewees. The major cause of construction accidents mentioned by interviewees is the lack of health and safety training of construction workers.

CT1 stated that:

"As most of construction workers do not know much about health and safety, the lack of training on health and safety measures exposes the workers and their colleagues to accidents."

In the absence of formal training of most construction workers, health and safety training workshops upgrade and enlighten workers about how to adhere to safety guidelines and plans as indicated by CT4 that:

"Most construction workers do not have any formal training, therefore complying with health and safety plan and policy is difficult to achieve. This, in a way, causes lot of construction accidents both on sites and off sites."

In this regard CT5 suggested that:

"Health and safety training and workshops must be organized periodically to workers. This would reduce the occurrence of construction accidents."

CT3 who considered lack of health and safety training of workers as a major cause of accidents observed that:

"Throughout the project period contractors do not allow time in the work plan for training on health and safety matters. Health and safety training workshop is important to be organized on projects which travel beyond three months to have a period of time within the work plan for health and safety training."

This was corroborated by all interviewees. It may be concluded that health and safety policies are mere documents that lack implementation during the construction period.

The second highest cause of accidents mentioned by the interviewees is inadequate equipment and tools.

"Inadequate equipment and tools most often lead workers to make an improvised equipment and tools to execute the work anyhow. It is usually it is like square pegs in round holes and most often, this cause accident at site (CT6)."

The third cause of accidents mentioned by the interviewees is lack of appropriate skills. It was stated that:

"The competency of a labour force provides a good safeguard to accidents (CT2).” 
Other interviewees lamented that:

"Many contractors engage labourers with low competency and lack of appropriate skills. Most contractors would want to reduce cost therefore engages low competent labourers at a cheaper cost (CT4)."

"This, however results in the high occurrence of the construction accidents (CT5)."

These responses suggest that most contractors hardly engage competent workers for construction works, thereby exposing the workers themselves, other workers and the public to lots of health hazards and risks. It is however important for contractors to engage workers who possesses the appropriate skills and are competent enough to handle most construction works.

\subsection{Construction Workers' Perspective}

Table 2 above shows the summary of responses by the Worker interviewees with six responses. The highest ranked cause of accidents, in the perspective of the interviewees is tiredness. For example, CW1 (also corroborated by CW2, CW4 and CW6) stated that:

"We always don't have time to rest and relax, always we are working. Tiredness together with complacency can cause great injuries to workers. Tiredness results in poor workmanship and bad attitude towards work which leads to lots of fatal injuries. Tiredness in itself is sickness, therefore when tired and still working, causes accidents not only to the worker himself but to other coworkers."

Construction workers were of the view that inadequate equipment and tools is the second cause of accidents at work sites. Most of the respondents corroborated with $\mathrm{CW} 3$ and $\mathrm{CW} 4$ that:

"Contractors like hiring less quality equipment which are often faulty and causes serious injuries to operatives on site and sometimes to other co-operatives. Most of the available equipment at the work site are faulty and therefore cause accidents (CW3)."

"Most equipment and tools available at site are faulty and when you are not lucky and the fault occurs in the course of work accident and or hazards are likely to occur. This has caused lot of injury to most of our colleagues (CW4)."

The advancement in construction requires the use of sophisticated equipment and tool for operations. The absence of appropriate equipment and faulty equipment often cause serious accidents on site.

The third highest cause of accident mentioned by the interviewees is lack of appropriate skills for specific works. They corroborated with CW5 that:

"When you are put on a task which you lack the necessary skills to execute you are likely to cause mistakes and accidents to yourself and other colleagues."

Most workers have weak financial background and are not able to train themselves with any skills, and therefore take up any unskilled labour job on site.

"Construction industry has room for the unskilled labor and therefore they 
end up being employed as unskilled labor (CW7)."

The Contractors are not in a position to afford or provide the necessary equipment and tools for specific works. CW6 lamented that:

"They usually put square pegs in round holes."

That is to say that wrong equipment was used for some works.

The Interviewees also mentioned that poor working conditions at work result in low level of concentration by workers on site, thereby causing accidents. The lack of concentration by workers results in the lack of focus on the particular operations being performed. CW3 pointed out that:

"Workers lose focus due to lots of pressure from supervisors and sometimes family. This forces the workers to work without the needed concentration level on the work."

CW1 lamented that:

"When there is due pressure on contractors and consultants to finish work within a particular time frame, they put pressure on us at site, this result in low level of concentration on activities to be done on site. The end of this is the cause of accidents and injuries to the worker and the public."

This was corroborated by CW4 and CW5.

From the views of the workers, the lack of proper facilities for the work and poor working environment cause lack of concentration on the work. The poor salary, absence of personal protective equipment, rest place and time, intimidation, insults and disrespect by supervisors, unclean environment, etc. are among the poor working conditions that caused loss of concentration to work mentioned by the workers.

\subsection{Suppliers/Manufacturers' Perspective}

In the perspective of suppliers, lack of training of workers on the proper use of materials and equipment causes accidents and hazards at the worksite. MS3 stated that:

"Non-reading of instruction on the usage of materials and equipment causes accidents."

MS7 also stated that:

"Lack of proper training on the use of materials and equipment are the causes of accidents."

The proper usage of materials on construction site is very crucial to ensure health and safety, and for quality construction project delivery.

MS4 pointed out that:

"Most construction workers and supervisors do not ensure the proper use of construction materials on site by training the workers who may use them. When materials are supplied on sites for specific works laborers often do not use them as expected or required of them because of lack of knowledge on the materials."

This was corroborated by MS5.

MS2 added that: 
"Training the workers will give them the needed knowledge to effectively use any material and subsequently avoid accidents and hazards. They use materials the way they see it without following the recommended guidelines, specification or instructions."

MS1 also added that:

"Even site supervisors who have to ensure the proper use of materials fail to do that and this causes injuries and skin diseases to users of such materials."

The absence of personal protective equipment (PPE) for construction workers was also indicated by interviewees as a major cause of construction accidents on site. The use of PPE plays a major role in protecting workers and visitors on construction sites. PPE such as helmet, safety boots etc. prevents direct injuries to operatives on site.

MS2 indicated that:

"PPE's does a lot of things to prevent injury to operatives and visitors on construction site. The absence of PPE is rampant and allows direct injuries and skin diseases to users of hazardous construction materials." This was corroborated by MS4.

MS1 also stated that:

"When workers use hazardous materials without protective clothing which cause lot of skin diseases and health injuries to users or workers."

Low level of education of workers was also identified by the interviewees as one of the causes of accidents at the construction site. Low level of education also impedes training programmes.

MS7 stated that:

"Even when workers are trained and provided with the necessary PPEs, the low level of education will not help them to appreciate the training and the use of the PPEs."

Bad attitude towards work was also identified by three of the interviewees as one of the causes of accidents at the work site.

MS3 stated that:

"Lack of enforcement of proper work attitude lead the trained and educated worker to be more careless and hence accident at the work place."

Proper attitude towards work and its enforcement should be embraced in the workers' health and safety charter.

\section{Discussion of Results}

The results in Table 2 show the factors that cause accidents and hazards in the GCI identified by the key stakeholders of the GCI: Contractors, Consultants, Construction Workers, and Manufacturers/Suppliers. A Pareto plot was used to rank the major causes of accidents and hazards, and for selecting the critical ones for remedying. From the Pareto plot (Figure 2), five major causes of accidents and hazards that are critical for remedying were identified as inadequate equipment and tools (F6), lack of health and safety training among stakeholders 


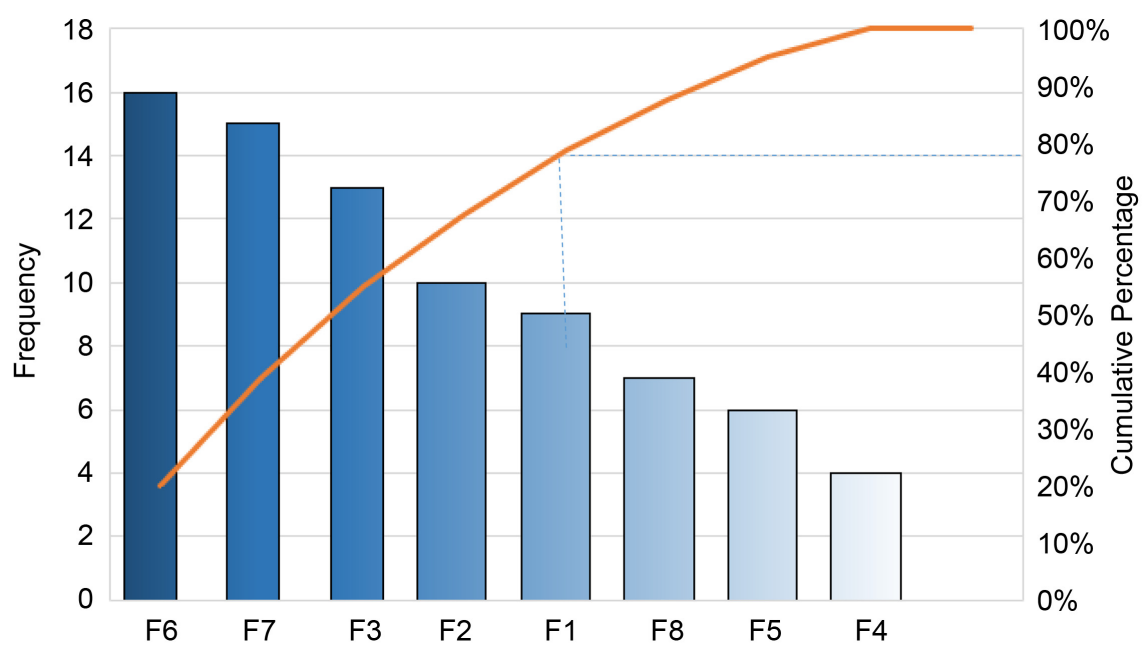

Figure 2. Causes of accidents and hazards in the Ghanaian construction industry.

(F7), lack of appropriate skills (F3), bad attitude towards work safety (F2), and poor working conditions and environment (F1).

The five critical factors accounted for $20 \%, 18.75 \%, 16.25 \%, 12.5 \%$ and $11.25 \%$ respectively of all the factors identified (Figure 2). The five critical factors, from the Pareto plot, form $78.75 \%$ of the contribution of all the eight factors identified in the studies and shown in Figure 3.

\subsection{Inadequate Equipment and Tools}

Inadequate equipment and tools, coded as F6, was identified as the most critical cause of accidents and hazards on construction sites and accounting for $20 \%$ of all the causes of accidents and hazards (Figure 2). Even though the contractors played down on F6 as a major factor, the consultants, suppliers and construction workers identified it as a major cause of accidents and hazards on site.

It is not surprising that the Contractors played down on F6 as it is the responsibility of the contractors to ensure that adequate equipment and tools are provided for workers to minimize the occurrence of accidents on site. Proper plant and equipment, according to literature, is one of the four common law liabilities of the Employer who is the Contractor in this study. This has been emphasized in the case of [31]. Contractors are not absolved from their duty to take care to provide proper appliance. This has been an ancient laid down duty of the employer as was held in [32] [33] [34] [35].

The laws of Ghana have observed the importance of adequate provision of equipment and tools and provided for it in [34]. Section 118(3) of [36] provides that employees are required to use the safety appliances, fire-fighting equipment and personal protective equipment (PPE) provided by the Employer, the default of which the employer shall not be liable for any injury sustained by the employee. Inadequate equipment and tools (F6), according to some contractors, is mainly due to the high cost of equipment and lack of continuous construction contract to sustain the payback of the cost of investment. This finding agrees 


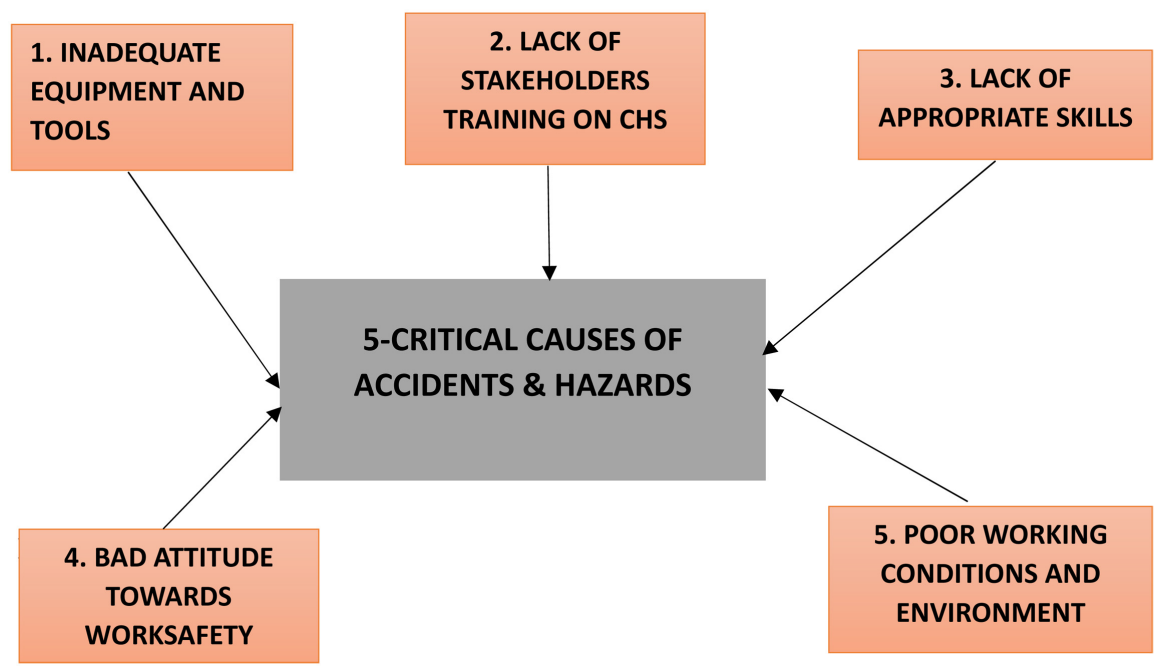

Figure 3. 5-Critical causes of accidents and hazards. Source: Authors.

with [37] who identified that the cost of acquiring adequate equipment for construction is high and so these contractors tend to provide less or any equipment they may lay hands on. The contractors, therefore, make do with any available equipment that may somehow be possible to do the work. This according to the contractors often leads to accidents and hazards. The courts have held that employers are liable where there is failure to provide proper appliances, maintain them in proper condition, and to carry on his operations so as not to subject those employed by him to unnecessary risk [38] [39] [40] [41].

The Workers, on their part, ascribed the inadequate equipment and tools to advancement in construction and the inability of contractors to invest in modern equipment and tools to keep abreast with the advancement. They also contended that faulty equipment or complete absence of equipment make the workers find any possible means to get the work done and this leads to accidents and hazards at the construction site. Improper use of equipment due to absence of appropriate equipment for specific works, lack of competent person to handle equipment and poor handling of the few equipments available, according to the consultants, cause accidents and hazards at the construction sites.

\subsection{Lack of Health and Safety Training of Workers}

The second most critical cause of accidents and hazards as identified by the Pareto plot (Figure 2) is "Lack of health and safety training of Workers coded as F7 in Table 2. This factor was more collaborative among Consultants, Workers and Suppliers. None of the Contractors mentioned F7 as a major cause of accidents and hazards. Lack of health and safety training of Workers accounting for $18.75 \%$ of all the factors was identified by the stakeholders. The Employers are obliged under [36] to provide necessary information, instructions and training to workers with regards to age and literacy level. The results show lack of compliance with the law for health and safety training of workers. Providing training on materials and equipment and the general working conditions is likely to re- 
duce the occurrence of accidents and hazards in the GCI. The provision of proper system of work, one of the common law duties of the employer identified in literature, includes the provision of training of workers on the use of materials and equipment. According to Wilson v Tyneside Window Cleaning Co [32] the master's duty to his servant is to take reasonable care so to carry out his operations as not to subject his servant to unnecessary risk. This is one single duty applicable in all circumstances. An effective health and safety training of workers will certainly satisfy the master's duty to his servant.

In the opinion of the suppliers, the low level of education of workers makes training difficult. This opinion is in agreement with the consultants. Health and safety policy and plan are difficult to interpret and implement during the construction period, according to the consultants. The suppliers observed that instructions, guidelines and specifications for use of materials and equipment are not adhered to due to low level of education, even when the workers are trained. Lack of Contractors interest in training the workers leads to non-training of the workers. The Consultants and the workers shared the same opinion that the main focus of the contractor is to complete the works by all means and not the safety of the Worker. In this regard, the low level of the knowledge of the worker on matters of health and safety often leads to accidents and hazards at the construction site.

\subsection{Lack of Appropriate Skills of Workers}

"Lack of appropriate skills" coded as F3 and accounting for $16.25 \%$ of all the factors was identified by stakeholders as the third most critical cause of construction accidents and hazards (Figure 2). This view also confirms the common law duty of employers to employ competent staff. The House of Lords in [34] held that "the employers were not absolved from their duty to take due care in the provision of a working safe of working by the appointment of a competent person to perform that duty."

Provision of competent staff is another employer's common law duty to his employees. Lack of appropriate skills among workers indicates failure of the employer to provide competent staff. The workers in the GCI are generally not well prepared for the task. This leads to accidents and hazards to themselves and the general public. The Workers were of the view that the GCI has room for unskilled labour and due to weak financial background to acquire skills, they end up being employed as such. Employers and Government should improve on institutions for the training of Construction Workers. Low level of education of workers may be the cause of the lack of appropriate skills and competent staff. Employers are therefore required to provide continuous training to upgrade the unskilled and skilled labour force. It was also agreed by both contractors and consultants that lack of appropriate skills among workers is expected in the GCI since the contractors are interested in employing cheap labour to reduce cost of doing business. Unskilled labour is cheap to recruit for construction works in 
Ghana, and is used after few years of working experience to perform the skilled labour work.

\subsection{Bad Attitude to Work by Workers}

"Bad attitude to work by workers" is considered the fourth critical cause of accidents and hazards in the GCI in the opinion of the stakeholders. The bad attitude to work, coded F2, accounted for $12.50 \%$ of all the factors. The bad attitude to work by workers may be linked with lack of competent staff or lack of appropriate skills which is the third most critical cause of accidents and hazards.

Contractors, Workers and Suppliers agree on the fact that F2 is a major cause of accidents and hazards. The Contractors stated that F2 is mainly due to the mistakes of the workers as they have little knowledge on the work they do, their carelessness or negligence and improper use of health and safety facilities and appliances. In the opinion of the Workers, pressure on the workers from contractors for completion of task, lack of proper facilities and poor working conditions for the work such as poor salary, absence of personal protective equipment, rest place and time, intimidation, insults and disrespect by supervisors, unclean environment, lack of provision of appropriate and suitable equipment and tools for specific workcause accidents and hazards. The Suppliers, however, consider bad attitude to work by workers to be the result of lack of supervision for the use of materials and equipment for the work assigned to workers.

The law states that an employee must show regard for his own safety and if he is injured as a result of his own negligence this may reduce or even extinguish the employer's liability. The law also states that the employee owes the employer a duty to exercise reasonable skill and care at his work and may be liable to his employer for causing injury in breach of his duty. Section 1 of [42], establishes that the employee contributes to the occurrence of the accident, an offence of contributory negligence, which reduces the liability of the employer. InKotiawusu v. Goka [43], the court held that "where in an action founded on negligence, apportionment of liability became necessary, the claimant's share in the responsibility was determined not only by the causative potency of his acts but also their blameworthiness." Generally, the courts have established the principle of vicarious liability, where the employer is liable for the acts of the employee. It has however been established in an exception to the general rule that, when the employee is not in the course of his employment, that is the employee is on the frolic of his own, the employer is not liable. In Yortuhor v. Brako and Another [44] the court held that "the master was only liable where the servant was acting in the course of his employer. If the servant was going out of his way against his master's implied commands, when on his master's business, the master would not be liable". The court held that for the employer to be liable, "the wrong must be expressly or implicitly authorized or incidental to something which the servant was employed to do."

The employer may be liable for some of these bad attitudes towards work if it 
is proved that the worker is inexperienced and not sufficiently trained, and adequate supervision has not been provided to curb such bad attitude towards work. Any bad attitude likely to cause any of the offences shall affect the health and safety of persons at the workplace and the general public, and shall make the employee liable.

\subsection{Poor Working Conditions and Environment}

The fifth most critical cause of accidents and hazards in the GCI was found to be "poor working conditions and environment", accounting for $11.50 \%$ of the identified factors. Sections 19, 20, 25, 26, 27, 28, 29, 30, 33, 34, 35, 36, and 37 of [45] as amended, provides the required basic working conditions for health and safety. These include the provision of sanitary facilities differently for each sex, adequate wholesome water in a suitable vessel if there is no standpipe-supply of water with the container being renewed at least daily and ensure that the water and the vessels are free from contamination; personal protective equipment (PPE) such as overalls, safety boots, goggles, and head covering to workers exposed to excessive wet, injurious and offence substance; reduction of noise at workplace through the adoption of appropriate and practicable measures; workers not to carry load which is likely to cause injury; availability of first aid box or cupboard during working hours; Regulations for noise control, vibrations, ventilations, washing facilities, lighting, measures in case of fire, proper safe means of access etc. by the Minister responsible for Employment. Other working conditions provided in [45] are safety measures to ensure the safe construction of floors, passage and stairs in buildings and other workplaces, provision of substantial handrail to every staircase in a building and openings in floors, proper construction and maintenance of ladders; provision of training and supervision for any person employed to operate a machine; competent and experienced persons to operate machines; regular cleaning of parts of a machine; prevention of women and young persons from cleaning a machine part or a prime mover; provision for the fencing of dangerous machinery, safeguard of transmission machinery and the construction and maintenance of the machine fencing respectively.

Sections 43 - 50 of [45] also provides for the use of heavy-duty machines and equipment such as crane, hoist, lifts, steam boilers etc. to be used in a safety manner without causing injury to operators. These working conditions are sometimes referred to as safe system of working.

According to [46], unsafe working conditions contribute to $10 \%$ of the rise in accidents and hazards on construction sites. Example of these accident causes according to [46], is a worker who finds a faulty equipment such as a ladder and fails to report to authorities for it to be fixed endangers the working environment and may cause an accident on another worker.

The law on provision of proper system of working is not limited to inexperienced workers but experienced and skilful workers as well. Employers may not deny a worker of proper system of working for the fact that he has the expe- 
rience to carry on the work. Professionals are equally guilty if they fail to conduct their work in accordance with acceptable standards.

Even though the working conditions outlined in [45] and [36] may not be exhaustive, it is important to note that all the scattered rules and laws related to construction health and safety in the Ghanaian laws identified in literature, when breached and injury is caused to another party, the party that breached the statute is liable for the offence of breach of statutory duty.

The offence of nuisance according to the court includes anything that causes annoyance [47]. In the Criminal Offences Act [48], noise has been identified as a tortious act. When an employer fails to control noise at workplace, which may interfere with the enjoyment of another, a worker or a visitor or a person of adjoining property, the employer is liable for the offence of tort of nuisance. The Criminal Offences Act [48] has identified public nuisance, including provision of unwholesome food, and throwing rubbish onto the street as offence. Employer's failure to provide proper working conditions of the employees and protecting the public from risk to injury shall make him liable. In CFC Construction Co. and Others v. Accra City Council [49], the court held that "the smell and vapours emanating from the refuse dumped in the quarry near the residences of the plaintiffs constituted a nuisance to them". The smell and vapour emanating from the environment of a construction worker may constitute an offence of nuisance.

The employer or contractor or the professional in providing proper working conditions must provide practices that are of the general standard of the reasonable man [50]. In Wilson \& Clyde Coal Co. Ltd v. English [34], House of Lords held that "to provide a proper system of working is a paramount duty, and, if it is delegated by a master to another, the master still remains liable. The employers were not absolved from their duty to take care in the provision of a reasonable safe system of working by the appointment of a competent person to perform that duty." Although the contractor may delegate his core duty of care, he remains liable in the event of injury or death of his employee.

\subsection{Conclusions and Recommendations}

The construction industry has a high number of fatalities and long-term injuries. This is unacceptable in modern society and it also makes the industry inefficient. This paper aimed at examining the causes of accidents and hazards in the Ghanaian construction industry from the perspectives of key stakeholders, and also the available legal regulations and provisions regarding remedies for redress in case of accidents. The study identified the following as the most critical causes of accidents and hazards requiring remedying: Inadequate Equipment and Tools, Lack of Health and Safety training among stakeholders; Lack of Appropriate Skills; Bad attitude towards work, and Poor Working conditions and environment among the eight factors identified as causes by stakeholders. All the factors are common law liabilities of the employer who is the Contractor in this in- 
stance, with a duty to ensure that adequate provisions are made to ensure that the works are carried out safely. The study agrees with the ancient employer's common law duties to his employees, which include the provision of 1) competent staff; 2) adequate safe place of work; 3) proper plant and equipment; and 4) a safe system of work or supervision as emphasized in the case of McDermid v. Nash Dredging [31] to improve on the implementation of CHS practices at construction sites. The findings of the study, therefore, provide adequate knowledge to the contractor and other stakeholders of the roles, duties, and responsibilities to ensure improved implementation of CHS practices. It is therefore recommended that all stakeholders play their respective roles in working together with the contractor in the performance of their common duties. The government is encouraged to strategically provide stimulus support to contractors in the provision of competent staff, adequate safe place of work, proper plant and equipment, and a safe system of work. The study examined the legal basis and consequence for the occurrence of accidents and hazards in the Construction Industry. Since large construction firms were considered in the current study, it is recommended that similar studies be conducted involving small and medium enterprises.

\section{Conflicts of Interest}

The authors declare no conflicts of interest regarding the publication of this paper.

\section{References}

[1] Jaafar, M.H., Arifin, K., Aiyub, K., Razman, M.R., Ishak, M.I.S. and Samsurijan, M.S. (2018) Occupational Safety and Health Management in the Construction Industry: A Review. International Journal of Occupational Safety and Ergonomics, 24, 493-506. https://doi.org/10.1080/10803548.2017.1366129

[2] Mock, C., Adjei, S., Acheampong, F., DeRoo, L.A. and Simpson, K. (2005) Occupational Injuries in Ghana. International Journal of Occupational and Environmental Health, 11, 238-245. https://doi.org/10.1179/oeh.2005.11.3.238

[3] Amponsah-Tawiah, K. and Mensah, J. (2016) Occupational Health and Safety and Organizational Commitment: Evidence from the Ghanaian Mining Industry. Safety and Health at Work, 7, 225-230. https://doi.org/10.1016/j.shaw.2016.01.002

[4] DeCamp, W. and Herskovitz, K. (2015) The Theories of Accident Causation. In: Security Supervision and Management, Butterworth-Heinemann, Oxford, 71-78. https://doi.org/10.1016/B978-0-12-800113-4.00005-5

[5] Sousa, V., Almeida, N.M. and Dias, L.A. (2014) Risk-Based Management of Occupational Safety and Health in the Construction Industry-Part 1: Background Knowledge. Safety Science, 66, 75-86. https://doi.org/10.1016/j.ssci.2014.02.008

[6] Biswas, G., Bhattacharya, A. and Bhattacharya, R. (2017) Occupational Health Status of Construction Workers: A Review. International Journal of Medical Science and Public Health, 6, 669-675. https://doi.org/10.5455/ijmsph.2017.0745302112016

[7] Bureau of Labor Statistics (2013) Employer-Reported Workplace Injuries and Illnesses 2012. United States Department of Labor. https://www.bls.gov/iif/oshsum.htm 
[8] U.S. Bureau of Labor Statistics (2014) Fatalities in the Construction Industry: Findings from a Revision of the BLS Occupational Injury and Illness Classification System. Monthly Labor Review.

[9] Ghana Statistical Service (GSS) Rebasing Report, 2019, Republic of Ghana.

[10] Ghana Investment Promotion Centre, Annual Report, 2006, Republic of Ghana.

[11] Dadzie, J. (2013) Perspectives of Consultants on Health and Safety Provisions in the Labour Act: A Study into Theory and Practicals. Engineering Management Research, 2, 34. https://doi.org/10.5539/emr.v2n1p34

[12] Asanka, W.A. and Ranasinghe, M. (2015) Study on the Impact of Accidents on Construction Projects. 6 th International Conference on Structural Engineering and Construction Management, Kandy, Sri-Lanka, 11-14 December, 2015, 58-67.

[13] Chong, H.Y. and Low, T.S. (2014) Accidents in Malaysian Construction Industry: Statistical Data and Court Cases. International Journal of Occupational Safety and Ergonomics, 20, 503-513. https://doi.org/10.1080/10803548.2014.11077064

[14] Hughes, P. and Ferrett, E. (2013) International Health and Safety at Work: The Handbook for the NEBOSH International General Certificate. Routledge, London. https://doi.org/10.4324/9780203096291

[15] Osei-Asibey, D., Ayarkwa, J., Adinyira, E., Acheampong, A. and Amoah, P. (2021) Roles and Responsibilities of Stakeholders towards Ensuring Health and Safety at Construction Site. Journal of Building Construction and Planning Research, 9, 90-114. https://doi.org/10.4236/jbcpr.2021.91008

[16] Ramachandran, P.N. (2011) Emergency Preparedness-An Action Plan for Industries. First International Seminar, SAFE99, on Safety \& Fire Engineering, Cochin, 24-26 November 1999, 55-64.

[17] Mwakali, J. (2006) Proceedings from the International Conference on Advances in Engineering and Technology (AET2006). Elsevier, Amsterdam.

[18] Li, R.Y.M. and Poon, S.W. (2013) Why Do Accidents Happen? A Critical Review on the Evolution of the Construction Accident Causation Models. In: Construction Safety, Springer, Berlin, 13-23. https://doi.org/10.1007/978-3-642-35046-7_2

[19] Omicini, A., Petta, P. and Pitt, J. (2004) Engineering Societies in the Agents World IV: 4th International Workshop, ESAW 2003, London, UK, October 29-31, 2003, Revised Selected and Invited Papers (Vol. 3071). Springer, Berlin. https://doi.org/10.1007/b98212

[20] Wong, F.K., Chan, A.P., Yam, M.C., Wong, E.Y., Kenny, T.C., Yip, K.K. and Cheung, E. (2009) Findings from a Research Study of Construction Safety in Hong Kong. Journal of Engineering, Design and Technology, 7, 130-142. https://doi.org/10.1108/17260530910974952

[21] Otley, D. (2016) The Contingency Theory of Management Accounting and Control: 1980-2014. Management Accounting Research, 31, 45-62. https://doi.org/10.1016/j.mar.2016.02.001

[22] Laryea, S. (2010) Health and Safety on Construction Sites in Ghana. The Construction, Building and Real Estate Research Conference of the Royal Institution of Chartered Surveyors, Paris, 2-3 September 2010. http://centaur.reading.ac.uk/

[23] Eyiah, A.K., Kheni, N.A. and Quartey, P.D. (2019) An Assessment of Occupational Health and Safety Regulations in Ghana: A Study of the Construction Industry. Journal of Building Construction and Planning Research, 7, 11-31. https://doi.org/10.4236/jbcpr.2019.72002 
[24] Strauch, B. (2017) Investigating Human Error: Incidents, Accidents, and Complex Systems. CRC Press, Boca Raton. https://doi.org/10.4324/9781315251851

[25] Tabish, S.Z.S. and Jha, K.N. (2011) Analyses and Evaluation of Irregularities in Public Procurement in India. Construction Management and Economics, 29, 261-274. https://doi.org/10.1080/01446193.2010.549138

[26] Flick, U. (2006) An Introduction to Qualitative Research. Sage, London.

[27] Gay, D.A., Morgan, F.D., Vichabian, Y., Sogade, J.A., Reppert, P. and Wharton, A.E. (2006) Investigations of Andesitic Volcanic Debris Terrains: Part 2-Geotechnical. Geophysics, 71, B9-B15. https://doi.org/10.1190/1.2159046

[28] Sandelowski, M. (2008) Reading, Writing and Systematic Review. Journal of Advanced Nursing, 64, 104-110. https://doi.org/10.1111/j.1365-2648.2008.04813.x

[29] Saunders, B., Sim, J., Kingstone, T., Baker, S., Waterfield, J., Bartlam, B., Jinks, C., et al. (2018) Saturation in Qualitative Research: Exploring Its Conceptualization and Operationalization. Quality \& Quantity, 52, 1893-1907. https://doi.org/10.1007/s11135-017-0574-8

[30] Fellows, R.F. and Liu, A.M. (2015) Research Methods for Construction. John Wiley \& Sons, Hoboken.

[31] House of Lords (1987) McDermid v. Nash Dredging [1987] Law Reports Appeal Cases Series, 1 A. C. 906, England.

[32] House of Lords (1958) Wilson v Tyneside Window Cleaning Co [1958] All England Law Reports 2 All ER 265, England.

[33] House of Lords (1951) Clifford v. Challen \& Son, Ltd. [1951] All England Law Reports, Court of Appeal. 1 All E.R. 72, C.A. England.

[34] House of Lords (1937) Wilson \& Clyde Coal Co. Ltd v. English (1937) All England Law Reports 3 All ER 628, England.

[35] House of Lords (1891) Smith v. Charles Baker \& Sons [1891] Law Reports Appeal Cases Series A.C.325, pg. 362, H.L. England.

[36] Republic of Ghana (2003) Labour Act, 2003 (Act 651). Assembly Press, Ghana Publishing Corporation of Republic of Ghana, Accra.

[37] Birhane, G.E., Yang, L., Geng, J. and Zhu, J. (2020) Causes of Construction Injuries. International Journal of Occupational Safety and Ergonomics, 1-26. https://doi.org/10.1080/10803548.2020.1761678

[38] Supreme Court of Ghana (1965) Goodman Moshie v Kwaku (1965) Ghana Law Reports, GLR 566, Accra.

[39] Supreme Court of Ghana (1967) Fibre Bag Manufacturing Co. v. Sarpong (1967) Ghana Law Reports, Court of Appeal, GLR 657 CA, Accra.

[40] Supreme Court of Ghana (1981) Ekem v. Wiseway Cleaners Ltd. (1981) Ghana Law Reports, GLR 801, Accra.

[41] Supreme Court of Ghana (1983) Korley v. State Construction Corporation (1982-83) Ghana Law Reports, GLR 576, Accra.

[42] Republic of Ghana (1963) Civil Liability Act, 1963 (Act 176). Assembly Press, Ghana Publishing Corporation of Republic of Ghana, Accra.

[43] Supreme Court of Ghana (1992) Kotiawusu v. Goka (1992) Ghana Law Reports, GLR 302, Accra.

[44] Supreme Court of Ghana (1990) Yortuhor v. Brako and Another (1989-90) Ghana Law Reports, GLR 429, Accra.

[45] Republic of Ghana (1971) Factories, Offices and Shops Act, 1971, (Act 328) Assem- 
bly Press, Ghana Publishing Corporation of Republic of Ghana, Accra.

[46] Schaufelberger, J. and Lin, K.Y. (2013) Construction Project Safety (Vol. 93). John Wiley \& Sons, Hoboken.

[47] Supreme Court of Ghana (1978) Ofori v Arthur (1978) Ghana Law Reports, GLR 112, Accra.

[48] Republic of Ghana (1960) Criminal Offences Act, 1960 (Act 29), Assembly Press, Ghana Publishing Corporation of Republic of Ghana, Accra.

[49] Supreme Court of Ghana (1964) CFC Construction Co. and Others v. Accra City Council [1964] Ghana Law Reports, GLR 496. Accra.

[50] Uff, J. (2005) Construction Law. Sweet \& Maxwell, London, 63-76. 